\title{
BEHAVIOR OF PRECAST REINFORCED CONCRETE BEAM-COLUMN EXTERNAL CONNECTIONS UNDER CYCLIC LOADING
}

\author{
AHMED TARABIA ${ }^{1}$, SAID ALLAM $^{1}$, EMAD ETMAN $^{2} \&$ MOHAMED ABOELHASSAN $^{1}$ \\ ${ }^{1}$ Department of Structural Engineering, Faculty of Engineering, Alexandria University, Egypt \\ ${ }^{2}$ Department of Structural Engineering, Faculty of Engineering, Tanta University, Egypt
}

\begin{abstract}
One of the main problems associated with beam-column precast connections is the lack of ductility and low shear strength. The main objective of this paper is to study experimentally the behavior of precast reinforced concrete beam-column external connections under cyclic loading and to improve the performance of shear resistance capacity for this connection type. This experimental study focused on the cyclic behavior of the bolted connection type, which is suitable for low level capacity of shear forces. In the proposed connection system, two factors were studied; firstly, introducing a shear key between column and beam in the connection zone, and secondly, studying the effect of adding shear reinforcement to this zone. Five external beam-column specimens were tested in the experimental program, including one monolithic specimen and four precast bolted connection specimens. Three variables studied in this paper were the effect of shear reinforcement in concrete shear key zone, the length of connection measured from the column face, and the location of threaded bars. All specimens were designed according to the concept of strong column and weak beam, and the specimens scale factor was two-thirds of a prototype structure in geometry according to ACI code. All specimens were loaded on the top of the column by a constant axial compressive load at the beginning of each test, and the reversed cyclic loading in accordance to a pre-described displacement history at the beam tip. The performance of the precast and monolithic connections was evaluated and compared on the basis of flexural strength, ductility, energy dissipation, and lateral drift capacity. The precast connections, with shear reinforcement at the shear key zone, exhibited higher flexural strength and initial stiffness when compared to the similar precast connection without shear reinforcement and the monolithic specimen. Keywords: precast concrete, reinforced concrete, beam-column connection, cyclic loading, exterior joint.
\end{abstract}

\section{INTRODUCTION}

The main concept of precast reinforced concrete structures (sometimes called prefabricated structures) includes a building in which the most structural components are prepared and produced in a factory away of the building, and after that, all components are moved to the project site for installation. In order to apply this concept to build a large number of structures at low cost and in a short time, these structural components are produced in the factory according to industrial methods with a mass production. The basic advantages of precast concrete structures are the high construction speed; which reduces total construction time of the project; a better quality control, and less requirement for labor. However, the basic weakness is the vulnerability of connections, particularly under seismic effects. A lot of precast concrete structures were heavily damaged by earthquakes. The main reason for this widespread damage was due to the poor performance of precast concrete connections. There are two types of beam-column joint connections, hinged connections and rigid connections (hard connections). In hinged connections, the beams are supported directly on columns by seating on corbels, for making the construction process easier and to transfer the shear forces from the beam to the column. However, rigid connections are used to make its performance similar to monolithic connections. Hard connections are those in which tensile, compressive, 
and shear stresses are transferred through special steel reinforcement and concrete details. There are three main requirements for precast concrete connections, which are the structural adequacy, the architectural function, and economy and speed [1].

Numerous experimental and analytical investigations have studied the performance and capacity of precast concrete connections, especially the detailing and location of precast connections. The behavior of welded precast beam-column connection was studied by Seckin and $\mathrm{Fu}$ [2]. In this study, simple connectors were introduced by using welded horizontal and vertical steel plates. It was concluded that precast connections performed as well as the monolithic connection and provided adequate ductility and maintained strength. Another experimental investigation for welded beam-column connections was presented by Ochs and Ehsani [3]. The results of this experimental program answered many questions about precast concrete connections and the relocation of plastic hinges, and the overall performance of the test specimens was found to be satisfactory. The post-tensioned precast concrete beam-column connections were presented in the experimental research conducted by Cheok and Lew [4] at NIST laboratory. It appeared that the performance of this connection type was strong and ductile as those of the monolithic connections, and the energy dissipation characteristics could be improved. A new precast technology was developed by Englekirk [5], where the major key to the concept was a ductile connector rod, which was embedded in a precast column, the overall performance of the ductile connector was better than that of the monolithic specimen. Stanon et al. [6] developed a new hybrid beam-column connection for precast frames, in which precast elements connected by unbonded post-tensioning steel and bonded reinforcing threaded bars. This connection proved to be at least similar to the monolithic connection in almost all respects, and superior in some aspects. Nakaki et al. [7] and Priestley et al. [8] presented an experimental study as a part of the PRESSS research program. A five-story precast concrete building with a sixty percent scale model was tested by using pseudo-dynamic test procedures. The building consisted of a wall system in one direction, and four different frame systems in the other direction. Hollow core slabs were used on two floors, while the other three floors were topped by double tees. It was reported that the behavior of the structure was extremely satisfactory, and the damage of the building for frame systems was much less than that of an equivalent monolithic building.

Another two-phase research program was developed for the same type of connections, in the first phase, the performance of four types of ductile precast beam-column connections and a reference monolithic specimen were studied by Ertas et al. [9]. It was concluded that the bolted connection response was more satisfying than the monolithic specimen in terms of energy dissipation. In the second phase, Ozden and Ertas [10] presented the results of tests performed on hybrid precast concrete connections, focused on the percentage of non-pre-stressed steel. The results showed that all precast specimens had an adequate flexural strength that could be sustained up to a $4 \%$ story drift without major strength degradation, and the design assumptions for using a $20 \%$ to $30 \%$ non-pre-stressed steel in a hybrid connection was better satisfied. Moreover, Ozden and Ertas [11] proposed a hysteretic moment-rotation modelling and an alternative section analysis. It was observed that the hysteretic behavior of the analytical model and experimental results were the same. Alcocer et al. [12] tested two full scale precast beam-column connections under unidirectional and bi-directional cyclic loading, this wet connection type had already been used in Mexico for commercial buildings with height up to $25 \mathrm{~m}$. The test results showed that the structural response of the precast frame was satisfactory. Khaloo and Parastesh [13] carried out a new proposed precast beam-column connection type, and their experimental investigation focused on the connection length and the transverse bars presence. It was concluded that the overall performance of the proposed connection was at least equivalent to the monolithic specimen. 
Similarly, Parastesh et al. [14] developed a new ductile precast beam-column connection, the proposed precast connections exhibited higher response compared to the similar monolithic. Also, Guan et al. [15] presented a similar experimental study, in which pre-stressing strands were placed at the bottom of the beam instead of steel bars. Based on the obtained results, the proposed precast connection could provide adequate seismic resistance similar to monolithic connections. Guan et al. [16] introduced a similar connection without using pre-stressing. In this study and to achieve continuity of the reinforcement of beam, longitudinal bar anchoring and lap splicing were used. The results proved that the performance of precast connection was better than monolithic connection. Khoo et al. [17] introduced another concept in their experimental study by using a modified assembled configuration for precast concrete frames in which the connections were constructed on the beam span and kept away from column faces, and the overlapping inside the connection was 90-degree (L-bent) and 180-degree (U-bent) hooks.

The results showed that the connections could perform satisfactorily. Similarly, Wahjudi et al. [18], [19] conducted an experimental and analytical study of constructible precast reinforced concrete connections with U-bent and L-bent hooks outside the beam-column joint. A numerical procedure had been carried out in the analytical study using the computer program software SeismoStruct, to predict the hysteretic response behavior of precast specimens. Generally, the analytical results showed a fair conformity with the experimental ones, and the precast connections demonstrated higher ductility than the equivalent monolithic specimen. Also, Yan et al. [20] presented a similar experimental study using precast pre-stressed concrete, where the beam end at column side had L-bent hooks and additional U-bent bars were placed at the beam-column joint. The results showed that the failure mode of precast and monolithic specimens was similar. Yuksel et al. [21] experimentally investigated two types of precast exterior beam-column connections, and also numerically modelled in OpenSees software platform. There were two types of connections industrial and residential connections, and the classification was according to the existence of corbels on the column. The results proved that the industrial type and residential type joint connections could be classified as low and medium ductility type connections, respectively. Similarly, Girgin et al. [22] presented a similar beam-column connection using steel plates, which were welded to the lower beam reinforcement. The results showed that while increasing the embedded upper reinforcement of beam, the relative energy dissipation ratio was raised.

The main objective of this paper was to study experimentally the possibility of improving the beam-column performance and the shear resistance capacity of bolted beam-column external connection under cyclic loading. The bolted connection was presented by Ertas et al. [9], with modifications were implementer to increase the shear resistance of this bolted connection. A shear key between column and beam was created in the connection zone, and shear reinforcement was added to this area.

\section{EXPERIMENTAL PROGRAM}

\subsection{Test specimens and connection details}

Five two-third scale exterior beam-column Specimens were tested in this experimental study, including one monolithic specimen (SP-M) and four precast bolted connections (SP-PC1, SP-PC2, SP-PC3, and SP-PC4). All specimens were designed according to the Egyptian Code ECP 203-2007 [23], and to satisfy the recommendation of ACI 318-14 [24]. In addition, 
all the precast concrete connections were followed the recommendations of the PCI Design Handbook [25]. The studied variables in this research are summarized in Table 1, which are:

1. The presence of shear reinforcement placed at the shear key zone.

2. The connection length (distance from the column face).

3. The location of the bolted threaded bars.

Table 1: Test variables and type of the test specimens.

\begin{tabular}{|c|c|c|c|c|}
\hline Specimen & Type & $\begin{array}{c}\text { Reinforcement at the } \\
\text { shear key }(2 \mathrm{row} \\
2 \phi 16 @ 100 \mathrm{~mm})\end{array}$ & $\begin{array}{c}\mathrm{L}, \\
\mathrm{mm}\end{array}$ & $\begin{array}{c}\text { Location of threaded } \\
\text { bars with respect to } \\
\text { beam cross-section }\end{array}$ \\
\hline SP-M & Monolithic & - & - & - \\
\hline SP-PC1 & Precast & Available & 400 & Middle \\
\hline SP-PC2 & Precast & Not Available & 400 & Middle \\
\hline SP-PC3 & Precast & Available & 600 & Middle \\
\hline SP-PC4 & Precast & Available & 400 & Corner \\
\hline \multicolumn{6}{|l}{ where L is the connection length (distance from the column face). } \\
\hline
\end{tabular}

To make the assembly process easier and to minimize tolerance, a hidden steel system was imbedded in the beam and column. This steel system consisted of two steel pipe sleeves with $36 \mathrm{~mm}$ diameter and $1.5 \mathrm{~mm}$ thickness located at the top and bottom of beams cross-section and through the column, to allow installation of the threaded bars during the assembly process. In addition, these steel pipes were welded at their end with steel plates at the top and bottom of beam cross-section to prevent concrete crushing at the beam face, and used as washers for the threaded bars on each side of the connection zone, these steel plates were connected to each other by two $10 \mathrm{~mm}$ diameter steel bars by welding. Also, to prevent the steel pipes from any possible sliding, $8 \mathrm{~mm}$ diameter steel bars were welded around the steel pipes as ribs and also steel bolts $10 \mathrm{~mm}$ diameter with $80 \mathrm{~mm}$ length were welded with the pipes as anchors. The tested specimens are:

- $\quad$ Specimen (SP-M): This monolithic specimen was used as a reference unit, the top and bottom longitudinal reinforcement of beam cross-section were continually passed through the column and bent at 90 degrees inside the column region (Fig. 1(a)).

- Specimen (SP-PC1): In this precast specimen, the shear reinforcement in the shear key area was added to improve the shear stiffness of the proposed precast concrete connection, and the length of connection was $400 \mathrm{~mm}$ (Fig. 1(b)).

- Specimen (SP-PC2): This test specimen was similar to SP-PC1, except that it was without shear reinforcement at the shear key zone, to study the effect of shear reinforcement (Fig. 1(b)).

- Specimen (SP-PC3): To study the effect of buckling of the bolted threaded bars, the precast connection length was increased to be $600 \mathrm{~mm}$. However, all the other details of this specimen were the same as Specimen SP-PC1 (Fig. 1(b)).

- Specimen (SP-PC4): The main purpose of this specimen was to study effect of the location of the bolted threaded bars in the beam cross-section, this specimen was similar to SP-PC1, except the location of threaded bars was changed to be at the outside corner of beam cross-section instead of the middle (Fig. 1(b)).

The proposed precast connection is detailed in Fig. 2. 


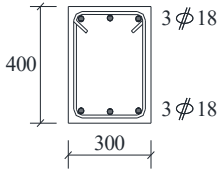

SECTION-1-(Beam)

Stirrups $\phi 8 @ 87.5 \mathrm{~mm}$ concrete cover $20 \mathrm{~mm}$
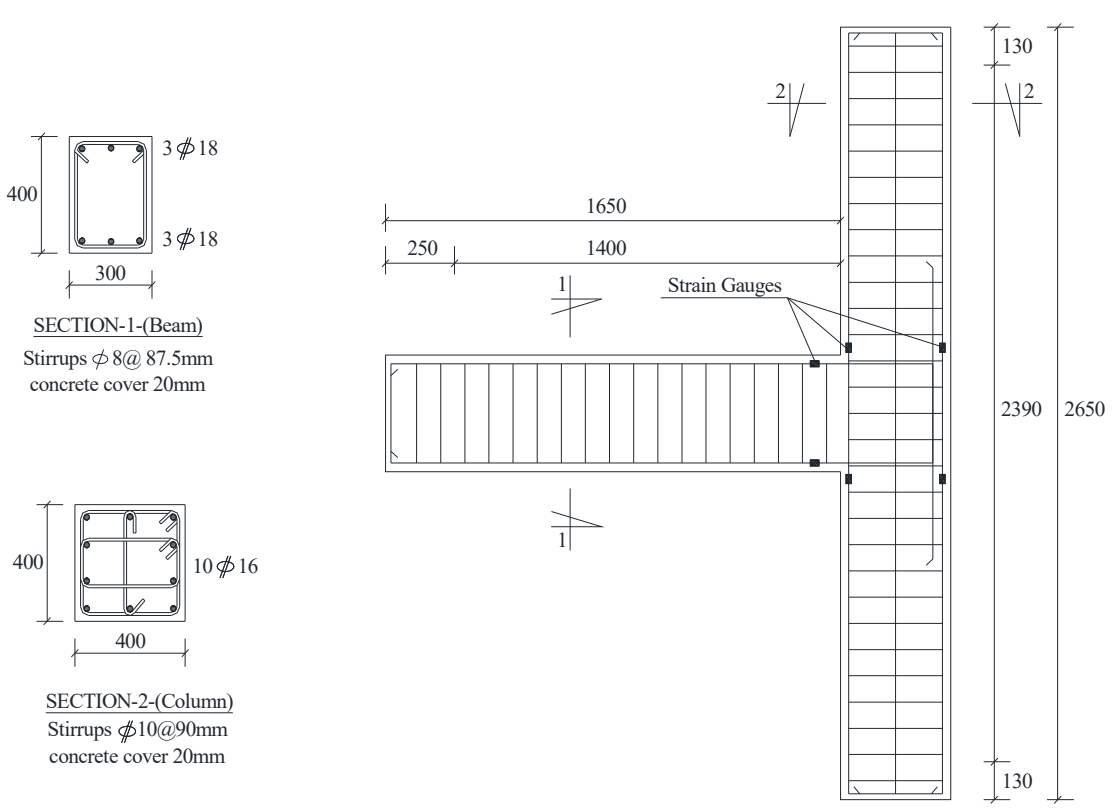

$\underline{\text { SECTION-2-(Column) }}$

Stirrups $\not 10 @ 90 \mathrm{~mm}$

concrete cover $20 \mathrm{~mm}$

All Dimensions in mn

(a)
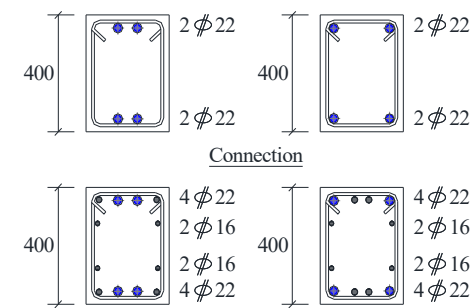
SECTION-3-(Beam)

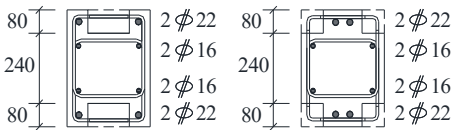
SECTION-2-(Beam)

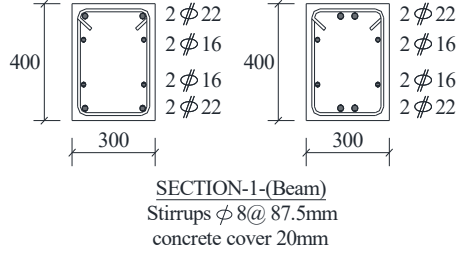

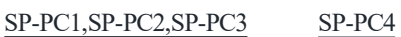

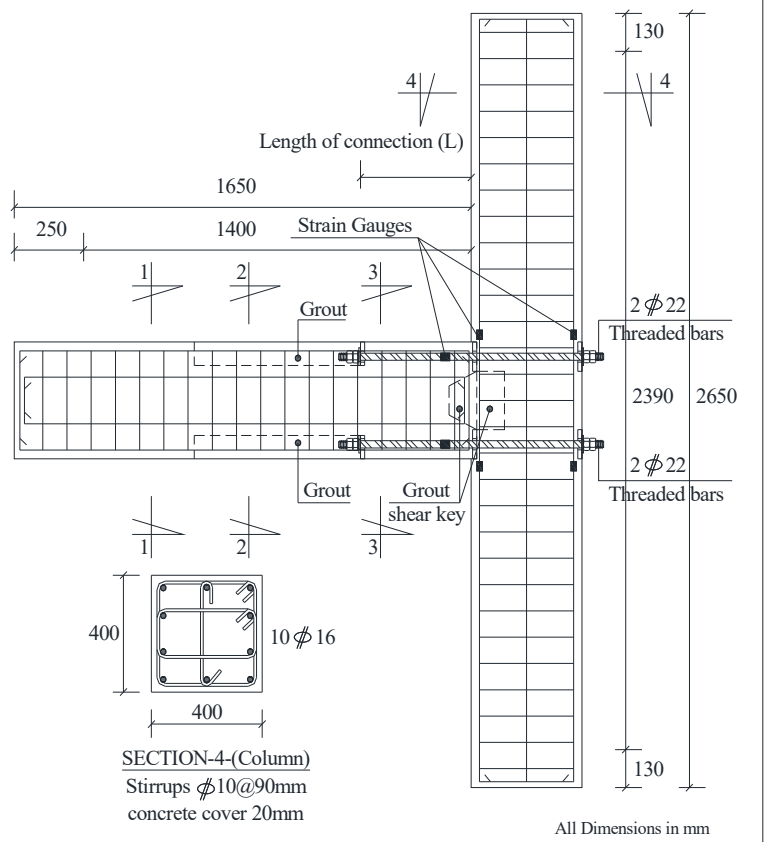

(b)

Figure 1: Reinforcement details of the specimens. (a) Monolithic specimen (SP-M); (b) Precast concrete specimens (SP-PC1, SP-PC2, SP-PC3, and SP-PC4). 


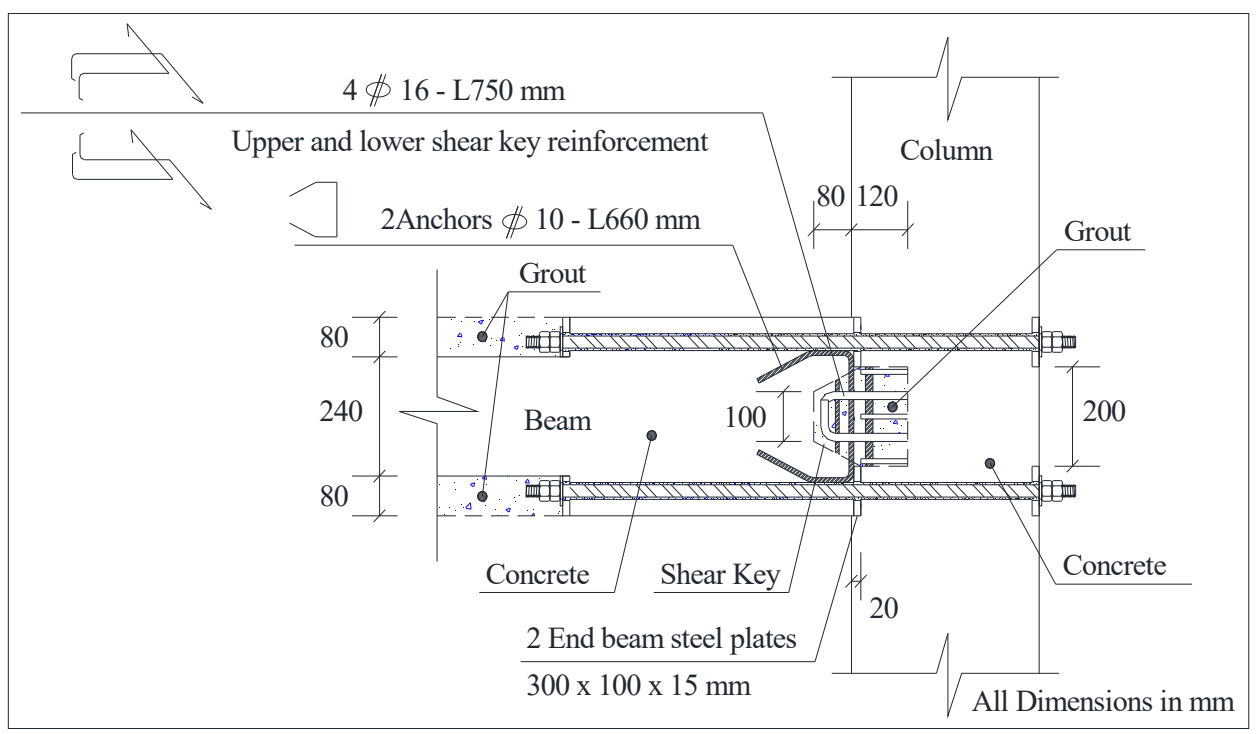

Figure 2: Detailing of the proposed precast connection.

\subsection{Design basis and geometry}

All specimens were designed according to the strong-column and weak-beam design concept. The prototype building had a plan of $20 \times 20 \mathrm{~m}$, column's spacing of $5 \mathrm{~m}$, and story height $3.50 \mathrm{~m}$ with total height $35 \mathrm{~m}$. The seismic design forces were calculated according to ECP 201-2012 [26], and the building was assumed to have enough ductile moment resisting frames. The scale factor was two-thirds of a prototype structure in geometry based on the ACI's T1.1R-01 [27].

For all monolithic and precast concrete specimens, ten $16 \mathrm{~mm}$ diameter bars $(\phi 16)$ were used in the column longitudinal reinforcement with a ratio of $1.25 \%$, and $10 \mathrm{~mm}$ diameter bars $(\phi 10)$ horizontal stirrups with spacing $90 \mathrm{~mm}$. However, for the monolithic specimen, three $18 \mathrm{~mm}$ diameter bars $(\phi 18)$ were used for the top and bottom of the beam cross-section, and for all precast specimens, two $22 \mathrm{~mm}$ and two $16 \mathrm{~mm}$ diameter bars ( $\$ 22$ and $\phi 16)$ for the top and bottom of the beams cross-section. Closed stirrups with $8 \mathrm{~mm}$ diameter bars $(\phi 8)$ with spacing $87.5 \mathrm{~mm}$ were used in beams for all monolithic and precast concrete specimens. The concrete cover thickness in all specimens for beams and columns was $20 \mathrm{~mm}$.

Six $150 \mathrm{~mm}$ standard concrete cubes were cast with each specimen and were cured in the same environmental conditions. These cubes were tested to determine the 28 days compressive strength $\left(f_{c u}\right)$, and the results are summarized in Table 2 . The reinforcement steel bars used in all columns were with grade $400 / 600$ for both the longitudinal and lateral reinforcement, and in all beams with grade 400/600 and 280/450 for the longitudinal reinforcement and stirrups, respectively. All precast concrete specimens were connected by a free-flowing micro-concrete grout (Sikacrete114), and the actual 28 days compressive strength $\left(f_{c u}\right)$ are listed in Table 2. Also, all the spaces between steel pipe sleeves and the bolted threaded bars were injected by a cement mortar supplied by an expanding aid additive, (IntraplastZ) with the cement mortar, and the tested 28 days compressive strength $\left(f_{c u}\right)$ are presented in Table 2. 
Table 2: Compressive strength of concrete and grout materials.

\begin{tabular}{|c|c|c|c|c|}
\hline Specimen & $\begin{array}{c}\text { Average } f_{c u} \text { of } \\
\text { concrete }\left(\mathrm{N} / \mathrm{mm}^{2}\right)\end{array}$ & $\begin{array}{l}C_{v} \\
(\%) \\
\end{array}$ & $\begin{array}{c}f_{\text {сu }} \text { of micro-concrete } \\
\text { grout }\left(\mathrm{N} / \mathrm{mm}^{2}\right)\end{array}$ & $\begin{array}{l}f_{c u} \text { of cement mortar } \\
\text { injection }\left(\mathrm{N} / \mathrm{mm}^{2}\right)\end{array}$ \\
\hline SP-M & 41 & \multirow{5}{*}{4.83} & \multirow{5}{*}{49} & \multirow{5}{*}{41} \\
\hline SP-PC1 & 45 & & & \\
\hline SP-PC2 & 46 & & & \\
\hline SP-PC3 & 46 & & & \\
\hline SP-PC4 & 46 & & & \\
\hline
\end{tabular}

All five specimens were cast in a horizontal position, and a level and smooth wooden mold was prepared for each specimen. In connection zone, the precast beam had a hollow shear key with the total width of the beam cross-section, and it was continuous through the column for $120 \mathrm{~mm}$ long. Also, hollow rectangular voids were made at the end of the connection zone at the top and bottom of the beam cross-section to allow the assembly process for bolting threaded bars. All voids were prepared using high density foam sheets for large spaces and spray foam in narrow places, which were removed before assembly process. All specimens were manufactured and poured in the Reinforced Concrete Laboratory, Faculty of Engineering, Alexandria University. The assembly process was made after 28 days from casting date. First, the beam was connected to column by placing the four threaded bars inside the steel sleeve pipes, and then, an initial pre-tensioning torque was applied to the threaded bars until the strain of threaded steel bars was about $10 \%$ of its yield value. After that, the shear key and the other voids of the connection were filled with the free-flowing micro-concrete grout, and all the steel pipe sleeves were injected with the cement mortar. After curing time, the specimens were transported and tested in the Reinforced Concrete and Heavy Structures Laboratory, Faculty of Engineering, Tanta University.

\subsection{Test setup and instrumentation}

All five specimens were tested while the column and beam in vertical and horizontal positions, respectively. The column was supported at its base on the strong beam of the lab structural frame, and the bottom and top ends of the column were prevented from horizontal movements but kept free to rotate as hinged supports. A vertical load equal to $498 \mathrm{KN}$ was applied using a vertical hydraulic jack with a load cell at the top of the column to apply the constant axial load, and a hydraulic ram actuator with a displacement range of $\pm 250 \mathrm{~mm}$ was used at the beam end to apply the lateral vertical displacement (Fig. 3).

Six Linear variable displacement transducers (LVDTs) were used to measure the joint rotation, gab opening and shear deformation at the connection zone and to ensure that no lateral horizontal movement occurred at column ends. In addition, six and eight strain gauges were installed on the longitudinal reinforcement of beams and columns at connection zone for the monolithic and precast concrete specimens, respectively (Fig. 1). These strain gauges were placed to measure uniaxial strain of steel reinforcement at critical locations, and to define the yield lateral displacement of the connection. 


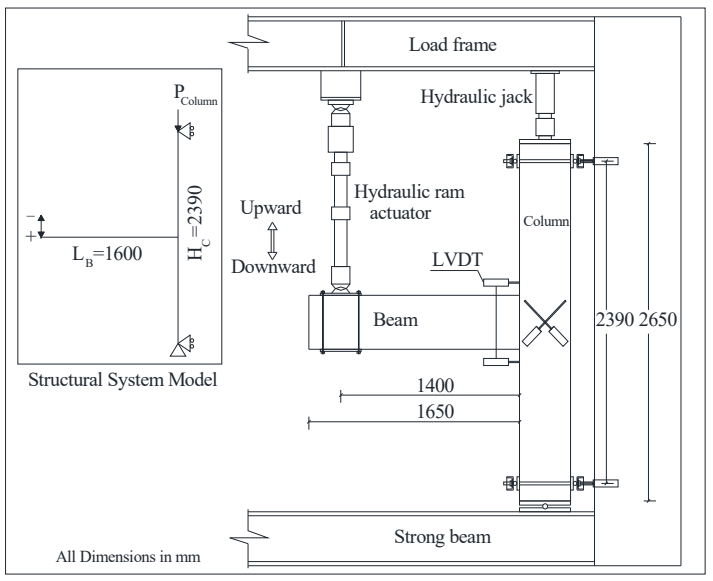

Figure 3: Test setup and boundary conditions for all specimens.

\subsection{Test procedure and loading sequence}

All experiments were conducted under the reserved displacement control lateral loadings at the beam tip according to ACI's T1.1R-01 [27]. These lateral loads were applied using a hydraulic ram actuator which moved in the upward and downward directions. The reverse cyclic loading was in accordance with a prescribed displacement history, consisted of displacement cycles of $\pm 2, \pm 3, \pm 4, \pm 5, \pm 7, \pm 10, \pm 15, \pm 20, \pm 25, \pm 30, \pm 50, \pm 70 \mathrm{~mm}$. Three fully reserved cycles were applied at each displacement level (Fig. 4). Also, to take into account the effect of the loads from upper floors, all specimens were loaded on the top of the column with a constant axial compressive load $498 \mathrm{KN}$ by a hydraulic vertical jack, where this axial load was equal to $10 \%$ of the cylinder compressive strength of concrete times the column gross cross-sectional area.

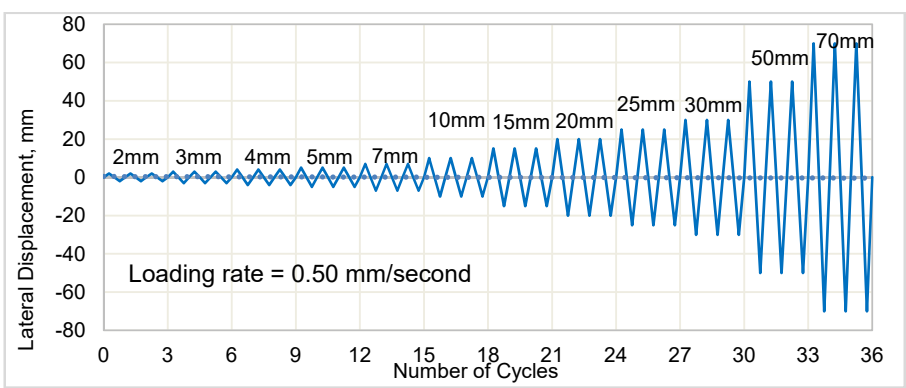

Figure 4: Cyclic loading history.

In this study, due to limitations of the test setup and to prevent damage of the hydraulic ram actuator, the test was terminated after completing three cycles at lateral displacement of $\pm 70 \mathrm{~mm}$ (more than $4 \%$ lateral drift ratio: see eqn (1)), where, $\Delta$ is the beam vertical displacement at the loading point and $\mathrm{L}_{\mathrm{B}}$ is the beam length from the equator centerline to the column centroid. All data were collected by a data acquisition system and loading rate 
was equal to $0.50 \mathrm{~mm} / \mathrm{second}$. Specimens were considered collapsed when the applied lateral load was less than $85 \%$ of the maximum actuator applied load, which is higher than the value (75\% of the maximum load) for the acceptance criteria based on ACI's T1.1R-01 [27].

$$
\text { Drift ratio }=\frac{\Delta}{L_{B}} \times 100 .
$$

\section{EXPERIMENTAL TEST RESULT AND ANALYSIS}

\subsection{Hysteretic behavior and failure mode}

The crack pattern and failure modes of all monolithic and precast specimens at the end of each test, as well as the hysteretic load displacement curves, are presented in Figs 5 and 6 , respectively. The crack patterns show that no diagonal or horizontal cracks occurred in columns at the beam-column zone for the all precast specimens, except in the monolithic specimen, visible horizontal hair cracks were observed at the column edge close to the beam.
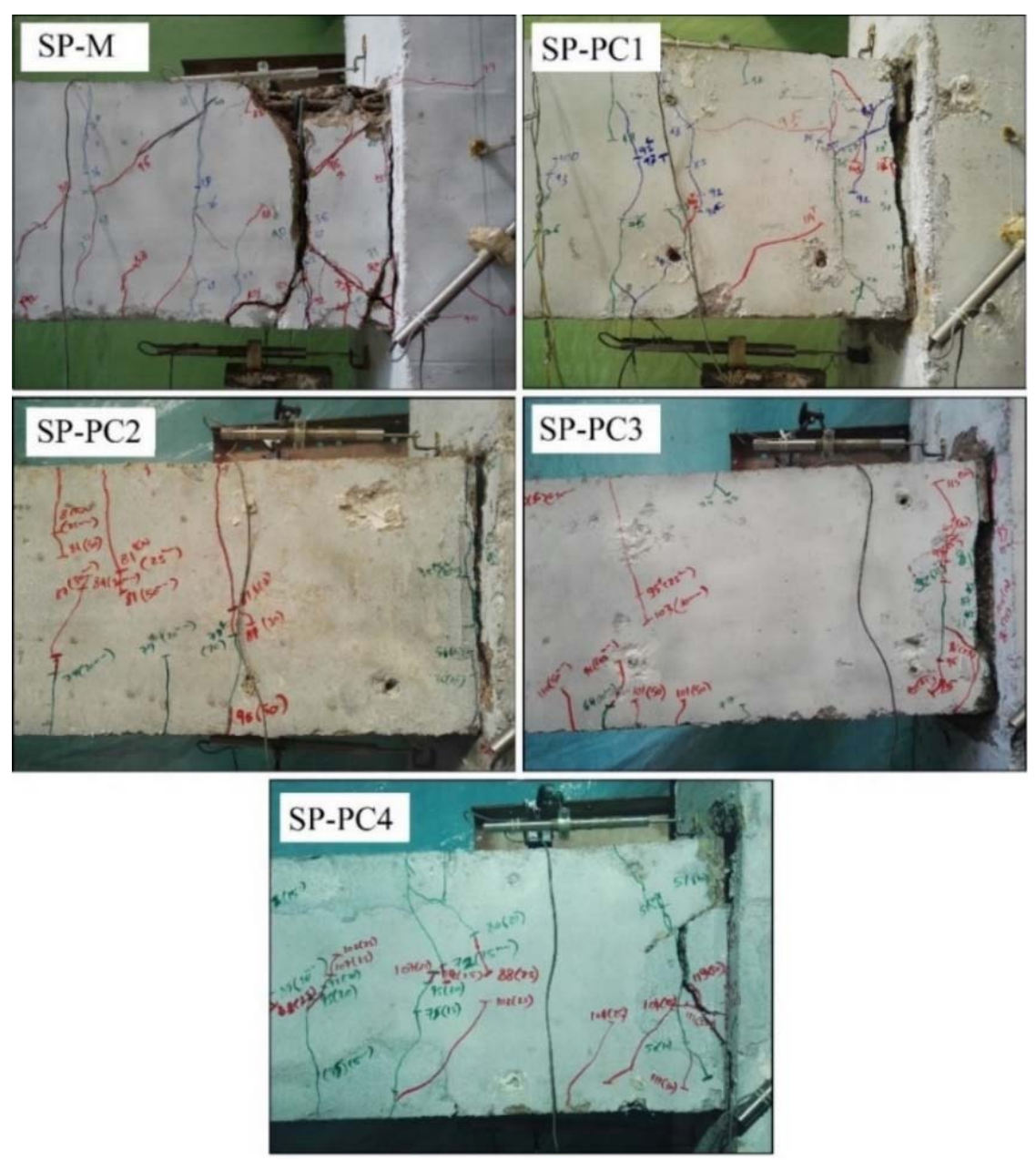

Figure 5: Crack pattern and failure modes of the test specimens at the end of each test. 


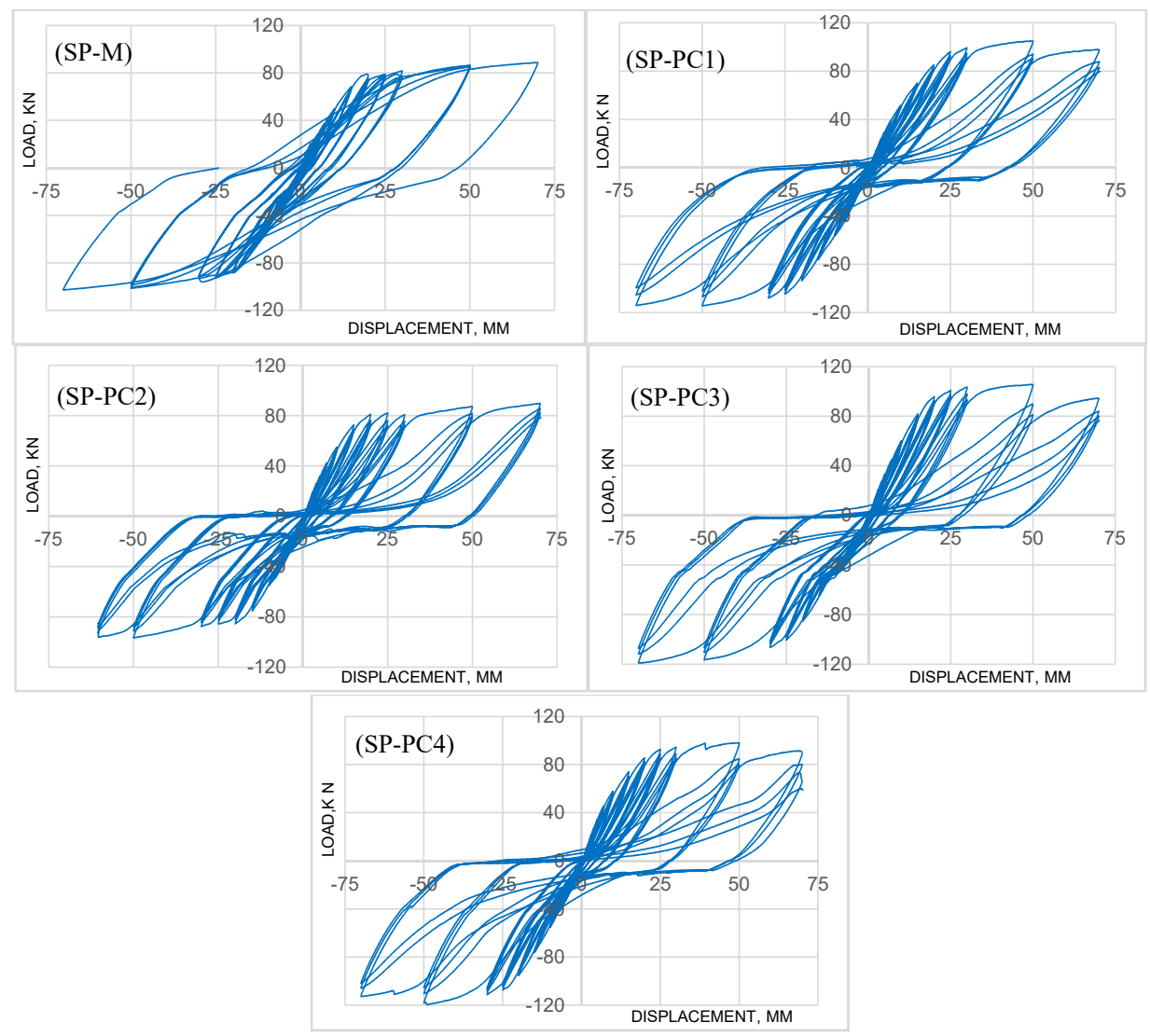

Figure 6: Hysteretic load displacement curves of the test specimens.

In addition, the hysteretic curves indicate that the pinching effect in monolithic specimen was lower than those of the precast specimens. The load displacement envelope curves show that there was a strength degradation in all precast specimens except SP-PC2 (Fig. 7). The yield and maximum vertical loads for upward and downward directions are listed in Table 3.

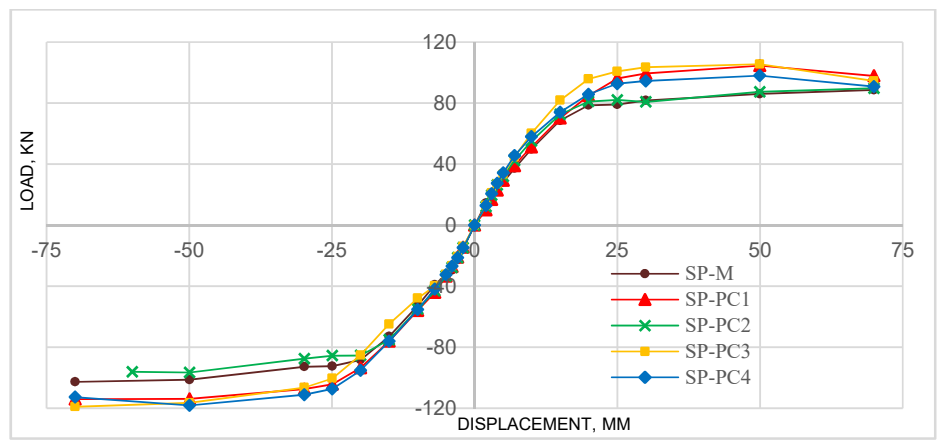

Figure 7: Load displacement envelope curves of the test specimens. 
Table 3: Test results and the ratio between experimental and calculated capacities.

\begin{tabular}{|c|c|c|c|c|c|c|c|c|}
\hline Specimen & $\begin{array}{c}\left(f_{c u}\right) \\
\mathrm{N} / \mathrm{mm}^{2}\end{array}$ & $\begin{array}{l}\text { Loading } \\
\text { direction }\end{array}$ & $\begin{array}{c}\mathrm{P}_{\mathrm{y}} \\
\mathrm{KN} \\
\end{array}$ & $\begin{array}{c}\mathrm{M}_{\mathrm{y}} \\
\text { KN.m } \\
\end{array}$ & $\begin{array}{l}\mathrm{P}_{\max } \\
\mathrm{KN}\end{array}$ & $\begin{array}{c}\mathrm{M}_{\max } \\
\text { KN.m }\end{array}$ & $\mathrm{R}_{\mathrm{y}}$ & $\mathrm{R}_{\max }$ \\
\hline \multirow{2}{*}{ SP-M } & & Downward & 78.25 & 109.55 & 88.66 & 124.13 & 1.00 & 1.08 \\
\hline & & Upward & 88.94 & 124.52 & 102.76 & 143.87 & 1.14 & 1.25 \\
\hline \multirow{2}{*}{ SP-PC1 } & \multirow{2}{*}{45} & Downward & 83.53 & 116.94 & 104.59 & 146.42 & 1.06 & 1.25 \\
\hline & & & 93.36 & 130.70 & 114.06 & 159.68 & 1.19 & 1.37 \\
\hline \multirow{2}{*}{ SP-PC2 } & \multirow{2}{*}{16} & Downward & 80.69 & 112.97 & 89.75 & 125.65 & 1.03 & 1.08 \\
\hline & & Upward & 84.08 & 117.71 & 96.60 & 135.24 & 1.07 & 1.16 \\
\hline \multirow{2}{*}{ SP-PC3 } & \multirow[t]{2}{*}{6} & Downward & 86.05 & 120.47 & 105.56 & 147.78 & 1.10 & 1.27 \\
\hline & & & 102.41 & 143 & & & 1.30 & .43 \\
\hline \multirow{2}{*}{ SP-PC4 } & \multirow{2}{*}{46} & Dou & 75.62 & 105.87 & 97.97 & 137 & 0.96 & 1.18 \\
\hline & & Upward & 96.81 & 135.53 & 118.14 & 165.40 & 1.23 & 1.42 \\
\hline \multicolumn{9}{|c|}{ 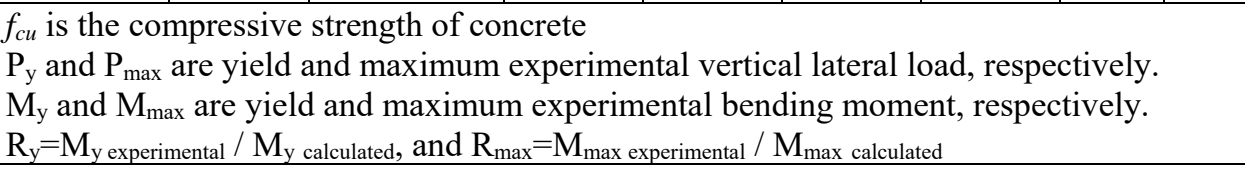 } \\
\hline
\end{tabular}

In the monolithic specimen SP-M, a minor flexural crack was observed at the top and bottom of the beam section at $0.625 \%$ drift ratio at a distance of $200 \mathrm{~mm}$ from the column face. The first diagonal crack in the beam was occurred at $1.25 \%$ drift ratio. Spalling of concrete at the beam near to the column face started at $3.1 \%$ drift level, and the beam upper longitudinal reinforcement buckled at $4.3 \%$ drift ratio.

In the precast specimen SP-PC1, when the drift ratio reached $0.45 \%$ and the actuator load was $38 \mathrm{KN}$, a hairline crack occurred at the beam-column interface, and this crack widened with the increase of the drift ratio. A hairline crack around shear key was observed at $0.65 \%$ drift ratio, and this crack widened from top side at $1.88 \%$ drift ratio. The first flexural cracks observed at a distance $450 \mathrm{~mm}$ from the column face at $0.5 \%$ and $0.94 \%$ drift ratio in upward and downward directions, respectively. Flexural cracks increased and were observed in other locations in the beam while the load and lateral drift ratio increased. A hairline diagonal crack beside the shear key was occurred at 3.5\% drift ratio.

The experimental performance of specimen SP-PC2 was similar to the monolithic specimen. The first visible crack was observed at $0.625 \%$ drift ratio and the load was $36 \mathrm{KN}$ at the beam-column interface. This hair crack was widened at $0.94 \%$ drift ratio. No flexural or diagonal cracks were occurred at beam inside the connection region. The first flexural crack was observed at the lower part of beam cross-section at $1.25 \%$ drift ratio and was located $400 \mathrm{~mm}$ away from the column face. The flexural cracks were continually observed at the top and bottom of the beam cross-section with increasing loads and lateral drift ratio.

In specimen SP-PC3, the initial visible crack in the specimen was observed at $0.45 \% \mathrm{drift}$ ratio at the beam-column interface. At $1.25 \%$ drift ratio and $92 \mathrm{KN}$ actuator load, a hair crack around the shear key was observed. Minor flexural cracks occurred at distance $600 \mathrm{~mm}$ from the column face at $1.56 \%$ drift ratio, and they spread when the drift ratio was $3.1 \%$. Also, at the same drift ratio level, the beam-column interface crack width increased to be more than $5 \mathrm{~mm}$. Crushing of the concrete cover was observed at $4.30 \%$ drift ratio near failure. It should be noted that the flexural cracks in this precast specimen (SP-PC3) was less than all other monolithic and precast specimens. 
In specimen SP-PC4, the first visible crack was observed at $0.625 \%$ drift ratio level, and the actuator load was $51 \mathrm{KN}$ at the beam-column interface. At drift ratio $0.94 \%$, a hairline crack around shear key and flexural cracks at both the upper and lower part of beam cross-section were observed at mid span of the beam, and this cracks widened with increasing drift ratio. A hairline diagonal crack near to the shear key occurred at $1.56 \%$ drift ratio. The width of crack around the shear key was more than $6 \mathrm{~mm}$ at $3.1 \%$ drift ratio.

\subsection{Flexural strength}

Based on the test setup, the bending moment of the specimen can be calculated as the applied load times the lever arms. The experimental values of yield and maximum bending moment for both directions are presented in Table 3. In addition, the yield and ultimate moment capacities of each specimen were calculated using a rectangular concrete stress block and actual yield and ultimate strength of steel reinforcement bars. The calculated values of the yield and ultimate bending moment capacities for monolithic specimen were 109.43 KN.m and 115.44 KN.m, respectively. However, the yield and ultimate bending moments for precast specimens were 109.90 KN.m and 116.69 KN.m, respectively. Based on the experimental results and from the ratio between the experimental bending moments to the calculated capacity, all connections achieved their calculated ultimate moment capacities. Also, the experimental results proved that the precast connections with shear reinforcement at the shear key zone (SP-PC1, SP-PC3 and SP-PC4) were about 18\% higher in flexural strength when compared to specimens SP-PC2 and SP-M (Fig. 7). In addition, it was noted that the load displacement envelope curves of specimens SP-PC2 and SP-M were identical.

\subsection{Displacement ductility}

Displacement ductility is a measure of the ability of the element or the structure to undergo plastic deformations without significant loss of strength. This concept is a critical parameter in the seismic design to avoid brittle failure, and it is defined as the ratio of the maximum ultimate displacement $\left(\Delta_{\mathrm{u}}\right)$ to yield displacement $\left(\Delta_{\mathrm{y}}\right)$. The yield displacement is defined by utilizing the load displacement envelope relationship based on the criteria used by Park (Fig. 8) [15]. The yield displacement is determined by satisfying that the area enclosed by the idealized bilinear curve up to peak point is equal to that by envelope curve.

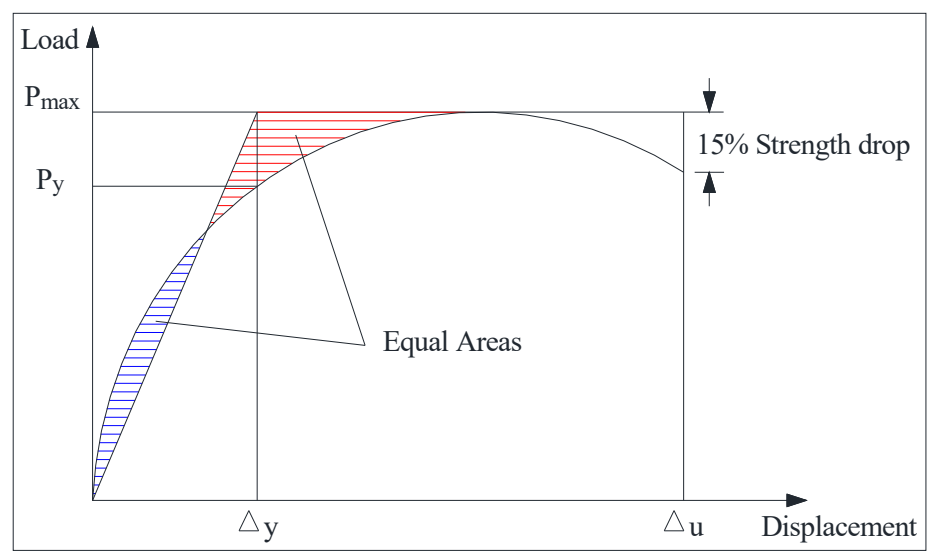

Figure 8: Equal energy principle [15]. 
The yield and ultimate displacements and displacement ductility are listed in Table 4, and these results showed that the all precast specimens behaved in a ductile manner as monolithic specimen. Also, Table 4 presents the ultimate drift ratio of each specimen (drift ratio at failure). According to ASCE 41-06 [28], reinforced concrete framed should resist inter-story drift ratios of $2 \%$ and $4 \%$ to reach life safety (LS) and collapse prevention (CP) performance level, respectively.

Table 4: Yield and ultimate displacements, displacement ductility, ultimate drift ratio, and the relative energy dissipation ratio.

\begin{tabular}{|c|c|c|c|c|c|c|c|}
\hline Specimen & $\begin{array}{l}\text { Loading } \\
\text { direction }\end{array}$ & $\begin{array}{c}\Delta_{\mathrm{y}} \\
(\mathrm{mm})\end{array}$ & $\begin{array}{c}\Delta_{\mathrm{u}} \\
(\mathrm{mm})\end{array}$ & $\mu$ & $\begin{array}{c}\mu \\
\text { average }\end{array}$ & $\begin{array}{c}\text { Ultimate } \\
\text { Drift ratio } \\
(\%)\end{array}$ & $\begin{array}{c}(\%) \\
\text { at } 3.50 \% \\
\text { drift ratio }\end{array}$ \\
\hline \multirow{2}{*}{ SP-M } & Downward & 19.52 & 70.00 & 3.59 & \multirow{2}{*}{3.38} & \multirow{2}{*}{4.38} & \multirow{2}{*}{36.40} \\
\hline & Upward & 22.03 & 70.00 & 3.18 & & & \\
\hline \multirow{2}{*}{ SP-PC1 } & Downward & 19.62 & 70.00 & 3.57 & \multirow{2}{*}{3.51} & \multirow{2}{*}{4.38} & \multirow{2}{*}{16.35} \\
\hline & Upward & 20.27 & 70.00 & 3.45 & & & \\
\hline \multirow{2}{*}{ SP-PC2 } & Downward & 19.59 & 70.00 & 3.57 & \multirow{2}{*}{3.55} & \multirow{2}{*}{4.38} & \multirow{2}{*}{14.86} \\
\hline & Upward & 19.89 & 60.00 & 3.52 & & & \\
\hline \multirow{2}{*}{ SP-PC3 } & Downward & 14.23 & 68.76 & 4.83 & \multirow{2}{*}{3.91} & \multirow{2}{*}{4.30} & \multirow{2}{*}{15.98} \\
\hline & Upward & 23.42 & 70.00 & 2.99 & & & \\
\hline \multirow{2}{*}{ SP-PC4 } & Downward & 15.84 & 64.06 & 4.04 & \multirow{2}{*}{3.74} & \multirow{2}{*}{4.00} & \multirow{2}{*}{17.82} \\
\hline & Upward & 20.40 & 70.00 & 3.43 & & & \\
\hline
\end{tabular}

Based on the results, the precast specimens SP-PC1 and SP-PC2 had the same drift ratio of the monolithic connection, and it was higher than that of SP-PC4, which indicates that the location of threaded bars in the middle of beam cross-section is better than placing them in the side corners. However, all specimens could achieve the CP performance level, and as a result, they could be used in high-seismic zones.

\subsection{Stiffness degradation}

The secant stiffness $\left(\mathrm{K}_{\mathrm{sec}}\right)$ was used for the comparison of the stiffness degradation. The secant stiffness is defined as the slope of the straight line between the maximum drift levels of upward and downward direction at the last load cycle of each successive story drift level (Fig. 9), and it is called peak-to-peak stiffness. In order to easily compare of all test specimens, each secant stiffness value was normalized $\left(\mathrm{K}_{\text {norm }}\right)$ by dividing the initial secant stiffness of each specimen. It was observed that stiffness degradation of all specimens was similar, especially specimen SP-PC1, SP-PC3, and SP-PC4 were very similar due to the shear reinforcement at the shear key zone (see Fig. 10).

On the other hand, specimens SP-PC2 and SP-M were identically, especially at a drift ratio more than $1.5 \%$. According to the acceptance criteria based on ACI's T1.1R-01 [27], the loss of initial stiffness at $3.5 \%$ drift ratio should have been not more than $95 \%$. The loss of initial stiffness of all specimens was approximately $79 \%$ to $83 \%$ at the end of the test, which is satisfying the acceptance criteria of the loss of initial stiffness. 


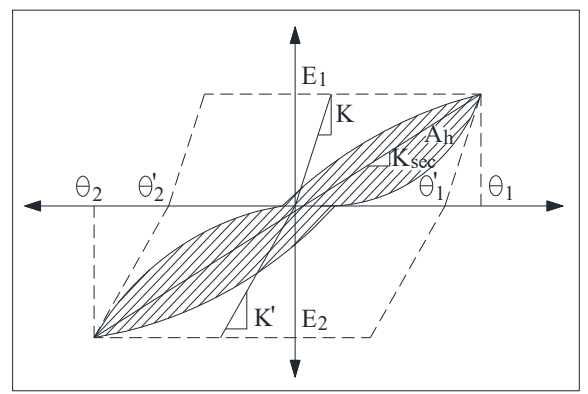

Figure 9: Secant stiffness and relative energy dissipation ratio [27].

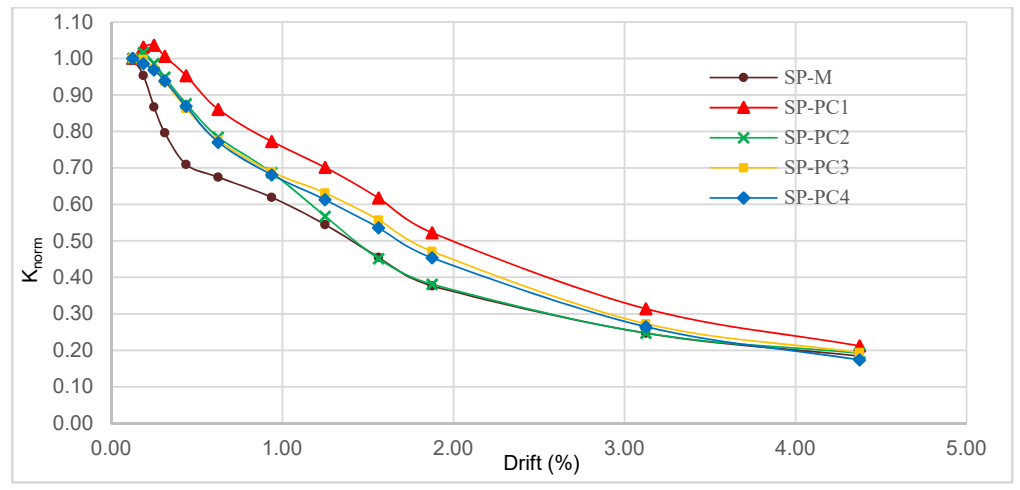

Figure 10: Normalized stiffness degradation of the specimens.

\subsection{Energy dissipation}

The relative energy dissipation ratio $\beta(\%)$ is defined by ACI's T1.1R-01 [27] as an acceptance criteria for design and evaluation of structures assigned to satisfy high seismic performance (Fig. 9). The dissipated energy can be measured as the hatched area $A_{h}$ of the hysteresis loop for the third cycle of a specific story drift level. The initial stiffness ( $\mathrm{K}$ and $\left.K^{\prime}\right)$ values and peak loads $\left(E_{1}\right.$ and $\left.E_{2}\right)$, at the drift ratio $\theta_{1}$ and $\theta_{2}$, may be different for the forward and reserve cycles. The relative energy dissipation ratio $\beta$ is the area $A_{h}$ divided by the area of the effective circumscribing parallelograms: see eqn (2). As an acceptance criteria based on ACI's T1.1R-01 [27], the relative energy dissipation ratio must not be less than $12.5 \%$ for the value of the third cycle at the $3.5 \%$ drift level.

$$
\beta(\%)=\frac{A_{h}}{\left(E_{1}+E_{2}\right)\left(\theta_{1}^{\prime}+\theta_{2}^{\prime}\right)} \times 100
$$

It was observed that the energy dissipation characteristic of all specimens was very similar until drift ratio $1.25 \%$ (average yield limit of the specimens), and then the monolithic specimen recorded a higher value (Fig. 11). The values of $\beta$ were high at the beginning of the test due to the linear response and the cracks were closed. At $2 \%$ drift ratio, $\beta$ values were in the range of $11.50 \%$ to $14 \%$ for the precast specimens, while $\beta$ value reached to $28 \%$ for the monolithic specimen. The calculated $\beta$ for specimens SP-M, SP-PC1, and SP-PC2 exceeded 
$12.5 \%$ at $2 \%$ drift ratio, while specimens SP-PC3 and SP-PC4 were slightly less than this required value. The $\beta$ values for SP-PC3 and SP-PC4 were $11.68 \%$ and $11.91 \%$, respectively. Based on the results, all monolithic and precast specimens satisfied the acceptance criteria for the relative energy dissipation ratio at $3.5 \%$ drift ratio. The $\beta$ value for all specimens at $3.50 \%$ drift ratio is listed in Table 4 .

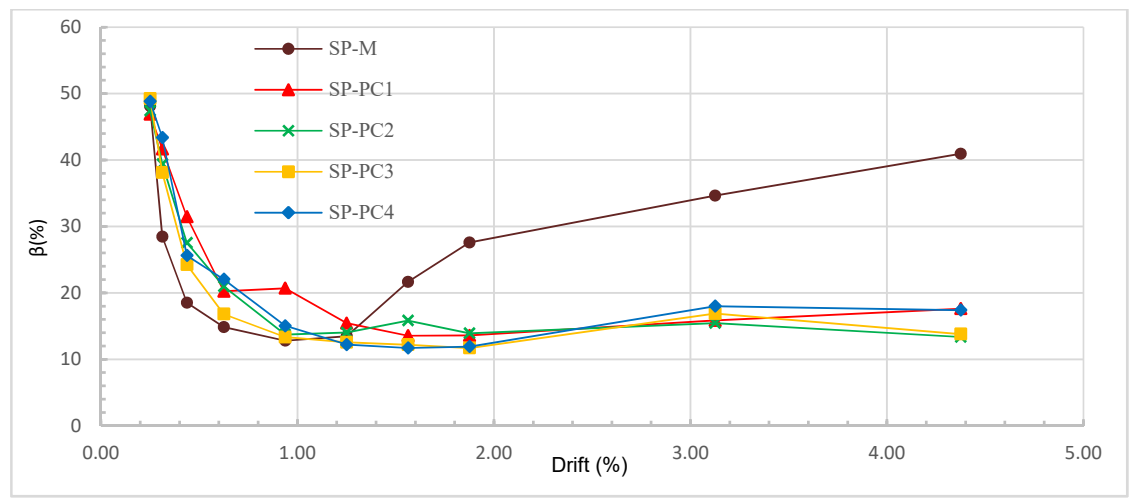

Figure 11: The relative energy dissipation ratio of the specimens.

\section{CONCLUSIONS}

The aim of this research was to study the cyclic experimental behavior of precast reinforced concrete bolted beam-column external connection, and to improve the performance and the shear resistance capacity. From the results obtained from the experimental cyclic loading testing on one monolithic and four precast specimens, the following conclusions may be drawn:

- All monolithic and precast specimens had adequate flexural strength that can be sustained up to $4 \%$ drift ratio. Moreover, the precast connections; with shear reinforcement at the shear key zone; exhibited higher flexural strength and initial stiffness when compared to the similar precast connection without shear reinforcement and the monolithic specimen.

- Considering the ductility factor, the results indicated that the all precast specimens behaved in a ductile manner similar to monolithic specimen, and all specimens could achieve the collapse prevention (CP) performance level.

- The stiffness degradation of all monolithic and precast specimens was similar, and the loss of initial stiffness of all specimens was approximately $79 \%$ to $83 \%$ at the end of the test.

- The energy dissipation characteristics of the monolithic and precast specimens satisfied the acceptance criteria for the relative energy dissipation ratio at $3.5 \% \mathrm{drift}$ ratio according to ACI's T1.1R-01 [27], while the specimens SP-PC3 and SP-PC4 were slightly less than the required at $2 \%$ drift ratio.

According to all above, the proposed bolted connection with shear reinforcement placed at the created shear key zone can provide adequate flexural strength, ductility, energy dissipation, and lateral drift capacity. Thus, this connection type can be used in high-seismic zones. 


\section{REFERENCES}

[1] FIB Bulletin 27, Seismic Design of Precast Concrete Building Structures, 2003.

[2] Seckin, M. \& Fu, H.C., Beam-column connections in precast reinforced concrete construction. ACI Structural Journal, 87(3), pp. 252-261, 1990.

[3] Ochs, J.E. \& Ehsani, M.R., Moment resistant connections in precast concrete frames for seismic regions. PCI Journal, 38(5), pp. 64-75, 1993.

[4] Cheok, G.S. \& Lew, H.S., Performance of precast concrete beam-to-column connections subject to cyclic loading. PCI Journal, 36(3), pp. 56-67, 1991.

[5] Englekirk, R.E., Development and testing of a ductile connector for assembling precast concrete beams and columns. PCI Journal, 40(2), pp. 36-51, 1995.

[6] Stanon, J., Stone, W.C. \& Cheok, G.S., A hybrid reinforced precast frame for seismic regions. PCI Journal, 42(2), pp. 20-32, 1997.

[7] Nakaki, S.D., Stanton, J.F. \& Sritharan, S., An overview of the PRESSS five-story precast test building. PCI Journal, 44(2), pp. 26-39, 1999.

[8] Priestley, M.J.N., Sritharan, S., Conley, J.R. \& Pampanin, S., Preliminary results and conclusions from the PRESSS five-story precast concrete test building. PCI Journal, 44(6), pp. 42-67, 1999.

[9] Ertas, O., Ozden, S. \& Ozturan. T., Ductile connections in precast concrete moment resisting frames, PCI Journal, 51(3), pp. 66-76, 2006.

[10] Ozden, S. \& Ertas, O., Behavior of unbonded, post-tensioned, pre-cast concrete connections with different percentages of mild steel reinforcement. PCI Journal, 61(4), pp. 32-44, 2007.

[11] Ozden, S. \& Ertas, O., Modeling of pre-cast concrete hybrid connections by considering the residual deformations. International Journal of the Physical Sciences, 5(6), pp. 781-792, 2010.

[12] Alcocer, M., Carranza, R., Perez-Navarrete, D. \& Martinez, R., Seismic tests of beamto-column connections in a precast concrete frame. PCI Journal, 47(3), pp. 70-89, 2002.

[13] Khaloo, A. \& Parastesh, H., Cyclic loading of ductile precast concrete beam-column connection. ACI Structural Journal, 100(3), pp. 291-296, 2003.

[14] Parastesh, H., Hajirasouliha, I. \& Ramezani, R., A new ductile moment resisting connection for precast concrete frames in seismic regions - An experimental investigation. Engineering Structures, 70, pp. 144-157, 2014.

[15] Guan, D., Guo, Z., Xiao, Q. \& Zheng, Y., Experimental study of a new beam-tocolumn connection for precast concrete frames under reversal cyclic loading. Advances in Structural Engineering, 19(3), pp. 529-545, 2016.

[16] Guan, D., Jiang, C., Guo, Z. \& Ge, H., Development and seismic behavior of precast concrete beam-to-column connections. Journal of Earthquake Engineering, 22, pp. 234-256, 2016.

[17] Khoo, J., Li, B. \& Yip, W., Tests on precast concrete frames with connections constructed away from column faces. ACI Structural Journal, 103(1), pp. 291-296, 2006.

[18] Wahjudi, D.I. et al., Behaviour of precast concrete beam-to-column connection with $\mathrm{U}$ and L-bent bar anchorages placed outside the column panel - Experimental study. Procedia Engineering, 95, pp. 122-131, 2014.

[19] Wahjudi, D.I. et al., Behaviour of precast concrete beam-to-column connection with $\mathrm{U}$ and L-bent bar anchorages placed outside the column panel - Analytical study. Procedia Engineering, 95, pp. 112-121, 2014. 
[20] Yan, X., Wang, S., Huang, C., Qi, A. \& Hong, C., Experimental study of a new precast prestressed concrete joint. Applied Sciences, 8(10), p. 1871, 2018.

[21] Yuksel, E. et al., Seismic behavior of two exterior beam-column connections made of normal-strength concrete developed for precast construction. Engineering Structures, 99, pp. 157-172, 2015.

[22] Girgin, S.C., Misir, I.B. \& Kahraman, S., Experimental cyclic behavior of precast hybrid beam-column connections with welded components. International Journal of Concrete Structures and Materials, 11(2), pp. 229-245, 2017.

[23] Ministry of Housing, Egyptian Code for Design and Construction of Reinforced Concrete Structures, ECCS203-2007, Egypt, 2007.

[24] American Concrete Institute, Building Code Requirements for Structural Concrete (ACI 318-14) and Commentary (ACI 318R-14), American Concrete Institute: Detroit, Michigan, USA, 2014.

[25] Precast/Pre-stressed Concrete Institute, PCI Design Handbook/7th Edition - (MNL120-10), Precast/Pre-stressed Concrete Institute: Chicago, USA, 2010.

[26] Ministry of Housing, ECP201-2012, Egyptian Code for Calculating Loads and Forces, Ministry of Housing: Egypt, 2008.

[27] American Concrete Institute (ACI) Innovation Task Group 1 and Collaborators and ACI Committee 374, T1.1R-01: Acceptance Criteria for Moment Frames Based on Structural Testing, ACI: Farmington Hills, MI, 2001.

[28] ASCE 41-06, Seismic Rehabilitation of Existing Buildings, 1st ed., American Society of Civil Engineering, 2007. 